\title{
Tales from the Supplementary Information: Ancestry Change in Chalcolithic-Early Bronze Age Britain Was Gradual with Varied Kinship Organization
}

\author{
Thomas J. Booth $\odot$, Joanna Brück, Selina Brace \& Ian Barnes
}

Large-scale archaeogenetic studies of people from prehistoric Europe tend to be broad in scope and difficult to resolve with local archaeologies. However, accompanying supplementary information often contains useful finer-scale information that is comprehensible without specific genetics expertise. Here, we show how undiscussed details provided in supplementary information of aDNA papers can provide crucial insight into patterns of ancestry change and genetic relatedness in the past by examining details relating to $a>90$ per cent shift in the genetic ancestry of populations who inhabited Chalcolithic and Early Bronze Age Britain (c. 2450-1600 BC). While this outcome was certainly influenced by movements of communities carrying novel ancestries into Britain from continental Europe, it was unlikely to have been a simple, rapid process, potentially taking up to 16 generations, during which time there is evidence for the synchronous persistence of groups largely descended from the Neolithic populations. Insofar as genetic relationships can be assumed to have had social meaning, identification of genetic relatives in cemeteries suggests paternal relationships were important, but there is substantial variability in how genetic ties were referenced and little evidence for strict patrilocality or female exogamy.

\section{Introduction}

Over the last decade, a step-change in DNA sequencing technology has led to a collapse in the cost of generating genetic information. The technology is particularly suited for application to degradedancient-DNA, and this has led to a large number of papers focused on the demographic prehistory of Europe (Skoglund \& Mathieson 2018). These studies tend to be broad in scope and draw inferences about population histories at a national or continental level over timescales of centuries to millennia. It can be difficult to reconcile these large-scale patterns of genetic change with local archaeologies. However, often hidden in the supplementary information which accompanies these papers are finer-resolution results that are more compatible with archaeological scales of analysis at the level of the individual site or region and are accessible without any specialist knowledge in genetics.

The primary aim of our paper is to demonstrate how consideration of hidden detail provided in the supplementary information of archaeogenetics studies can provide fresh insights into ancestry change and genetic relatedness. We show how these insights can be combined with other types of archaeological data to develop more reflexive narratives of the past by assessing data pertaining to the genetics of Chalcolithic-Early Bronze Age (C-EBA: c. $2450-1600$ BC) Britain provided in the supplementary information of Olalde et al. (2018). In particular, we critically examine suggestions that ancestry change in C-EBA Britain was characterized by a sudden large-scale migration of males practising

Cambridge Archaeological Journal 31:3, 379-400 @ The Author(s), 2021. Published by Cambridge University Press on behalf of the McDonald Institute for Archaeological Research. This is an Open Access article, distributed under the terms of the Creative Commons Attribution licence (http:// creativecommons.org/licenses/by/4.0/), which permits unrestricted re-use, distribution, and reproduction in any medium, provided the original work is 
strict systems of exogamy, as has been suggested for other areas of Europe in the third and early second millennia BC (Kristiansen et al. 2017; Sjögren et al. 2020). If this was the case for Britain, we would expect to see an initial pulse followed by a rapid decline of ancestry related to Neolithic populations of Britain, representing initial exogamous pairings between incoming men and local women and then rapid displacement of local ancestry (Furtwängler et al. 2020). At a higher resolution, in single cemeteries we would expect to see agnatic genetic ties between burials of men who grew up locally, an absence of local adult female genetic relatives and a greater abundance of non-local females who are largely horizontally unrelated to local males (Mittnik et al. 2019; Sjögren et al. 2020).

Olalde et al. (2018) identified a $>90$ per cent replacement of ancestry relating to Neolithic populations in C-EBA Britain. This involves the first appearance of so-called 'steppe-related ancestry'. Populations with 'steppe-related ancestry' are at least partly descended from people who lived around the Pontic-Caspian steppe and parts of Eastern Europe c. 3000 BC (Allentoft et al. 2015; Haak et al. 2015; Narasimhan et al. 2019; Wang et al. 2019). Similar shifts in ancestry have been identified in other parts of Europe in the third millennium BC around the same time as the Corded Ware and Bell Beaker phenomena, and they have been interpreted as indicating long-distance movements of people who brought with them new material cultures and mortuary practices. Kristiansen et al. (2017) propose that the dispersal of steppe-related ancestry into parts of eastern and central Europe was driven by 'war bands' of young male pioneers settling new territories. They argue that these groups practised exogamous marriage with women from local groups who did not carry steppe-related ancestry. Their focus is on the development of Corded Ware groups in central Europe, but they imply that similar mechanisms were responsible for the dispersal of steppe-related ancestry and early Indo-European languages across Europe through the third millennium BC (cf. Mittnik et al. 2019; Sjögren et al. 2020).

This model has been extrapolated to the point of caricature in popular outlets which have evoked images of marauding horsemen pillaging their way across Europe and the Channel (Barras 2019). Both academic and popular interpretations of the increase in steppe-related ancestry have been the focus of much debate, and the underlying assumptions regarding the relationship between genetic ancestry, cultural identity and social practice have been called into question (e.g. Carlin 2018; Frieman \& Hofmann 2019; Furholt 2018; Hakenbeck 2019; Vander Linden 2016). In fact, we do not yet understand the processes involved in this ancestry shift. The idea that it necessarily involved dramatic events such as large-scale migrations or 'wipe-out' of local populations by violence, disease, or both, are grounded in the apparent rapidity of ancestry change.

Although these models provide convenient explanations for certain aspects of the data, the inferences they draw are problematic, for they create visions of past societies where significant social change was initiated solely by men and reproductive success is defined in terms of biological rather than social reproduction. Isotope analyses indicate that women also moved during the Chalcolithic and Early Bronze Age (Knipper et al. 2017; Parker Pearson et al. 2019b; Price et al. 2004), but while male mobility is viewed as the result of activities such as warfare and trade, women are figured as passive objects of exchange in exogamous patterns of marriage (Frieman et al. 2019). Women, it is argued, moved as wives, while men moved as significant social agents. The language of nineteenth-century evolutionism is reflected in the image of young male war-bands whose aggressive, competitive actions reflect an innate drive to attain political and economic domination. We can call into question the double standards that pervade this difference in the interpretation of male and female mobility. Equally, it is important to consider other modes and mechanisms of inter-community interaction that might have resulted in the genetic changes that have been documented.

Models of abrupt population replacement are particularly problematic in a British context because of the archaeological evidence for significant cultural continuity across the Late Neolithic-Chalcolithic transition (Cleal \& Pollard 2012; Gibson 1982; Needham 2005; Parker Pearson et al. 2016; 2019a). Late Neolithic Grooved Ware ceramics continued to be made well into the second half of the third millennium, for example, while sensitivity to and knowledge of Late Neolithic cultural practices are evident in the influence of Neolithic motifs on Early Bronze Age ceramics, as well as continued interest in significant locations of Neolithic date, notably monuments. Ritual practices such as pit deposition that span the Late Neolithic to Early Bronze Age, as well as the presence of persistent places such as flint scatters that include characteristically Late Neolithic and Beaker tool types, speak of continuity and syncretism rather than disruption and replacement. 
Tales from the Supplementary Information

\section{Population change in Chalcolithic-Early Bronze Age Britain}

Previously published genetic evidence from continental Europe suggests that groups carrying steppe-related ancestry intermarried with local populations (Fernandes et al. 2020; Furtwängler et al. 2020; Linderholm et al. 2020; Mathieson et al. 2018; Olalde et al. 2018; 2019). Movements of people into C-EBA Britain therefore introduced mixed steppe-related and pre-steppe-related ancestry from various regions of continental Europe. The $>90$ per cent population replacement figure for Britain refers to this accumulated mixture of ancestries. Steppe-related ancestry, calculated using admixture models with Early Bronze Age populations from various sites around present-day Samara as a source, accounts for around 50-60 per cent of ancestry in C-EBA populations of Britain, while the rest comprises accumulated ancestries related to populations who inhabited various regions of Europe during the Neolithic (Olalde et al. 2018). For ease of discussion, we refer here to the mixed post- and presteppe-related ancestry from continental Europe as 'steppe-related continental' ancestry, although we stress that populations of continental Europe contemporary with C-EBA populations of Britain were genetically dynamic and heterogeneous.

The Chalcolithic to Late Bronze Age sample set from Britain comprises 101 individuals, 19 dating to the Chalcolithic (2450-2150 BC), 52 to the Early Bronze Age (2150-1600 вс) and 31 to the MiddleLate Bronze Age (1600-800 BC: Supplementary Table 1). The C-EBA individuals share greatest genetic affinities with EBA populations dating to the late third and early second millennium $\mathrm{BC}$ from Oostwoud, present-day Netherlands (Olalde et al. 2018). Most of the burials sampled from Oostwoud are some centuries later than the relevant samples from Britain, and so it is unlikely that the Oostwoud population represents the precise source of population movements into Britain (Fokkens et al. 2017). The paucity of genetic data from other regions such as northern France means that sampling bias undoubtedly affects any attempt to identify particular geographical origins for C-EBA populations in Britain. A parsimonious interpretation of the genetic evidence is that populations who moved into Britain predominantly came from the lower Rhine Valley, but the data are still consistent with arguments based on the archaeological evidence that groups moved into Britain from various different parts of northern continental Europe (Parker Pearson et al. 2019b).
Given archaeological evidence for cultural continuity, one particularly pressing question is why Neolithic ancestry is not more apparent in the C-EBA sample from Britain. When we look at the detailed information on patterns of admixture in the supplementary information of Olalde et al. (2018, supplementary information table S9), a high (35/55, 67 per cent) proportion of archaeogenetic samples from Britain dating to between 2450 and 2000 вс show little to no ( $0-5$ per cent) detectable ancestry related to populations who inhabited Britain during the Neolithic, considering standard errors around ancestry estimates (Olalde et al. 2018; Fig. 1). However, five individuals carry substantial proportions (20-40 per cent) of ancestry related to British Neolithic populations throughout the same period, a proportion compatible with one of their grandparents deriving the majority of their ancestry from the Neolithic population of Britain. The latest individual showing substantial ancestry (35 per cent) from the British Neolithic is a female from the East Kent Access Road site in Kent (Sk 220053), radiocarbon dated to 2131-1890 cal. BC (3625 \pm 35 вг, SUERC-40718). This suggests the persistence of unsampled C-EBA populations whose ancestry was largely derived from the Neolithic inhabitants of Britain and who intermarried infrequently with the sampled population. Beginning around $2100 \mathrm{BC}$, there is a small but marked increase in general levels of ancestry derived from the Neolithic population of Britain. Around the same time, we cease to see individuals carrying substantial ancestry ( $>20$ per cent) related to British Neolithic populations. This ancestry shift seems to represent an increase in rates of intermarriage between groups with divergent affinities to Neolithic populations (Olalde et al. 2018). Date ranges (95 per cent confidence) of C-EBA samples that show either little-to-no or substantial amounts of ancestry related to the Neolithic populations of Britain are all earlier than or overlap $2000 \mathrm{cal}$. BC. On average these samples derive 6 per cent of their ancestry from the populations of Neolithic Britain. The same figure is significantly higher at 12 per cent (one-tailed Wilcoxon rank sum, $\mathrm{W}=497, \mathrm{p}<0.05)$ for all later samples where ancestry related to Neolithic Britain has largely homogenized, indicating that there was a small but significant resurgence of ancestry related to Neolithic populations of Britain after 2100 BC. We would not expect to see such a persistence of ancestry related to the Neolithic populations of Britain if large-scale migrations from continental Europe $\sim 2450$ вС had rapidly displaced the local population. 


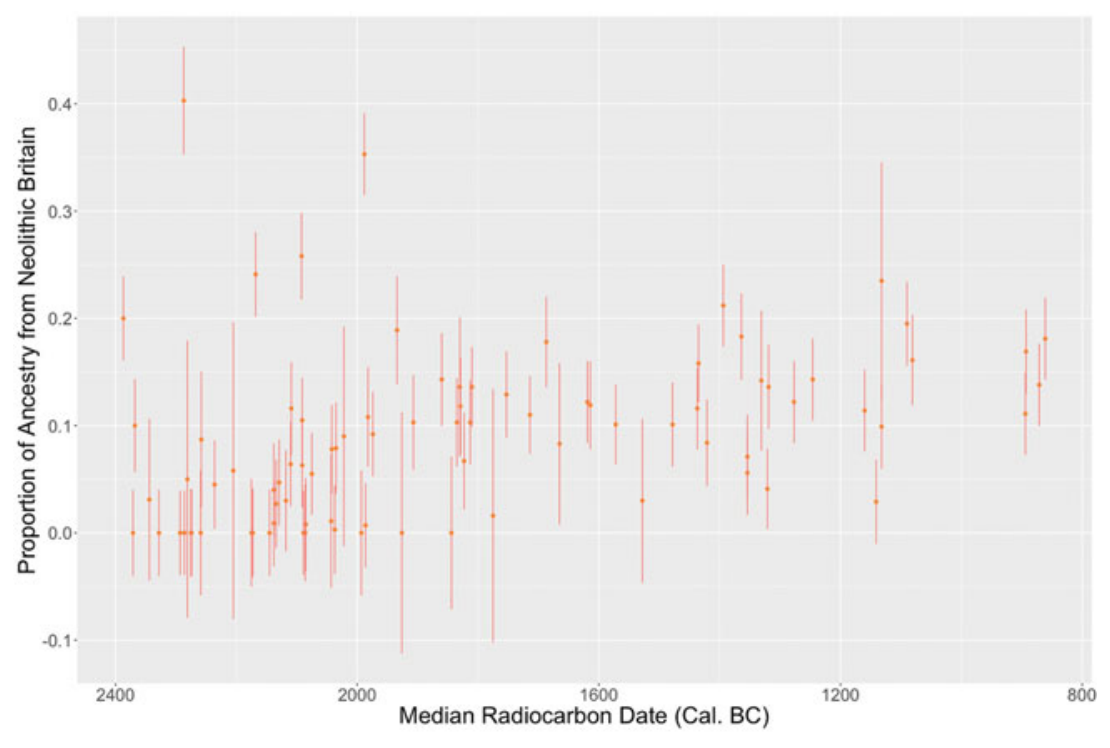

Figure 1. Proportion of ancestry related to the Neolithic populations of Britain through time with standard errors in radiocarbon-dated samples from Britain reported in Olalde et al. (2018). (This figure was generated using ggplot2 in RStudio: Wickham 2016; RStudio Team 2020.)
A caveat is that it is currently difficult to distinguish between ancestry from Neolithic populations of Britain and more western areas of continental Europe where we have little relevant archaeogenetic data but which represent archaeologically plausible sources of population movements, such as presentday northern France (Olalde et al. 2018; Parker Pearson et al. 2019b). If people from western areas of northern Europe harboured more ancestry from local Neolithic populations than we see in the Oostwoud Beaker burials, it is possible that migrations into Britain from these regions could account for some of the Neolithic ancestry we see in samples from C-EBA Britain. However, the limited amounts of archaeogenetic data we have from Bronze Age burials from present-day France indicates that these populations had similar levels of steppe-related ancestry to sampled populations of C-EBA Britain (Brunel et al. 2020; Olalde et al. 2018; Rivollat et al. 2020). Therefore, while some of the variability in genetic affinities to Neolithic populations of Britain we see in C-EBA samples may be attributable to variability in continental source populations, it is more likely this variation largely relates to interactions with groups carrying substantial ancestry from British Neolithic populations directly.

Why is genetic continuity from Neolithic Britain not more manifest in the C-EBA archaeogenetic dataset? This dataset predominantly comprises unburnt single articulated burials, although there is diversity, including disarticulated and multiple burials from a range of funerary contexts (Olalde et al. 2018). Cremation is the most commonly recognized funerary rite in Late Neolithic Britain immediately before the first appearance of populations carrying steppe-related continental ancestry, although the number of known Late Neolithic burials of any sort is small, suggesting most of the dead were treated in ways that are archaeologically invisible. Cremation continues as a minority rite through the Chalcolithic before becoming the most common form of mortuary practice in the Early Bronze Age (Appleby 2013; Bloxam 2019; Cummings 2017; Willis et al. 2016). To date no workable quantities of genome-wide data from ancient cremations have been reported. As Parker Pearson et al. (2019b) suggest, the underrepresentation of C-EBA groups genetically more affiliated with British Neolithic populations may be explained by the continuation of cremation practices or funerary rites which left no archaeological trace (Fig. 2). Some under-detected continuity of Neolithic populations in Britain would help to account for Late Neolithic cultural influence through C-EBA Britain. There is archaeogenetic evidence from other areas of prehistoric Europe that groups with distinctive ancestries coexisted in certain regions for hundreds and even thousands of years, including groups variably carrying steppe-related ancestry (Bollongino et al. 2013; Furholt 2019; Furtwängler et al. 2020; Lipson et al. 2017; Mathieson et al. 2018; Olalde et al. 2019). In these regions of Europe, too, after apparent major genetic transformations of local ancestries, there are frequent later appearances of people carrying substantial ancestry from earlier periods, which is similarly indicative of sampling bias in archaeogenetic analyses towards people with particular ancestries practising highly archaeologically visible funerary rites (Furholt 2019). 


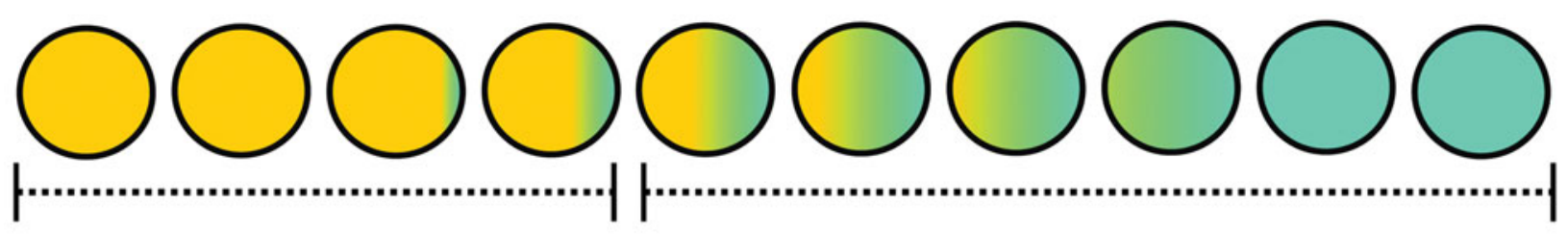

More Likely Afforded Highly Visible Funerary Rites

More Likely Cremated or Afforded Less Visible Funerary Rites

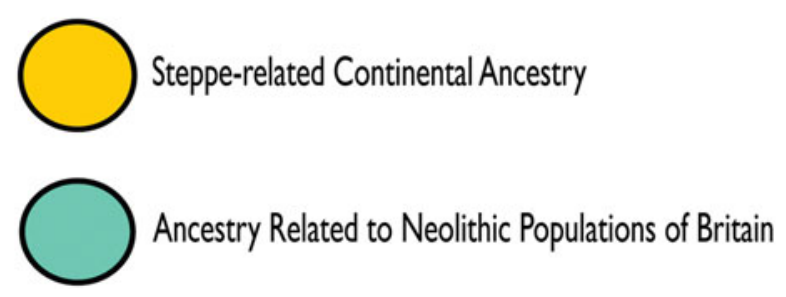

Figure 2. Illustration of the model proposed to explain the underrepresentation of C-EBA groups with substantial affinities to Neolithic populations.

Groups derived from British Neolithic populations could selectively have adopted and reinterpreted aspects of Beaker lifestyles while continuing to cremate their dead. So, too, in-marrying men and women with steppe-related continental ancestry might have adopted some of the cultural practices (including cremation) of the communities in which they came to live, so that genetic admixture in this direction might go unnoticed. Cremated human bones have been found in typical Beaker funerary contexts such as stone cists and are sometimes accompanied by Beaker pots (Appleby 2013). However, human cremations are also recovered from some Bell Beaker burials in continental Europe, so we cannot assume C-EBA cremations in Britain represent individuals with greater genetic affiliations to British Neolithic populations (Drenth 2014; Turek 2008). It should be stressed nonetheless that genetic ancestry and cultural affiliation are not coterminous (Carlin 2018; Furholt 2018): it is possible that an individual with steppe-related continental ancestry did not identify as culturally different to neighbours with Neolithic ancestry.

Examining the occurrence of close genetic relatives identified by Olalde et al. (2018, supplementary table 1, column 14) shows another possible bias in the C-EBA sample set and perhaps the C-EBA funerary record more generally (Supplementary Table 2). Close genetic relatives are identified in large-scale archaeogenetic studies by examining lengths and percentages of shared DNA sequences (Kuhn et al. 2018; Schroeder et al. 2019; Vai et al. 2020). The specificity of relationships can vary depending on the method used, but generally relatives are often classed as either 1st order (sharing 50 per cent of their DNA-e.g. siblings, parent-child), or 2nd-3rd order (sharing 12-25 per cent of their DNA, e.g. grandparents, great-grandparents, uncles, aunts or cousins). Probable relationships can be further elucidated through looking at mitochondrial and Y-chromosome haplogroups (maternal and paternal lineages), ages-at-death and the relative or absolute chronological order of burials. Some of these relatives are excluded from the main analyses presented in archaeogenetic papers, as the inclusion of too many close relatives can affect the results. Therefore, these genetic relatives are often only identified in supplementary information.

Twelve out of 21 (57 per cent) C-EBA burials sampled from Wiltshire, the region of Britain from which we have the highest density of samples, were close genetic relatives (1st-3rd degree). Eight out of 11 C-EBA burials (72 per cent) from Amesbury Down specifically were close genetic relatives (Olalde et al. 2018). Numbers of relatives in these cemeteries are likely to be even higher than this when we consider the probable presence of nongenetic kin, such as spouses or other family members who were not biological relatives, and 'cryptic' kin, 


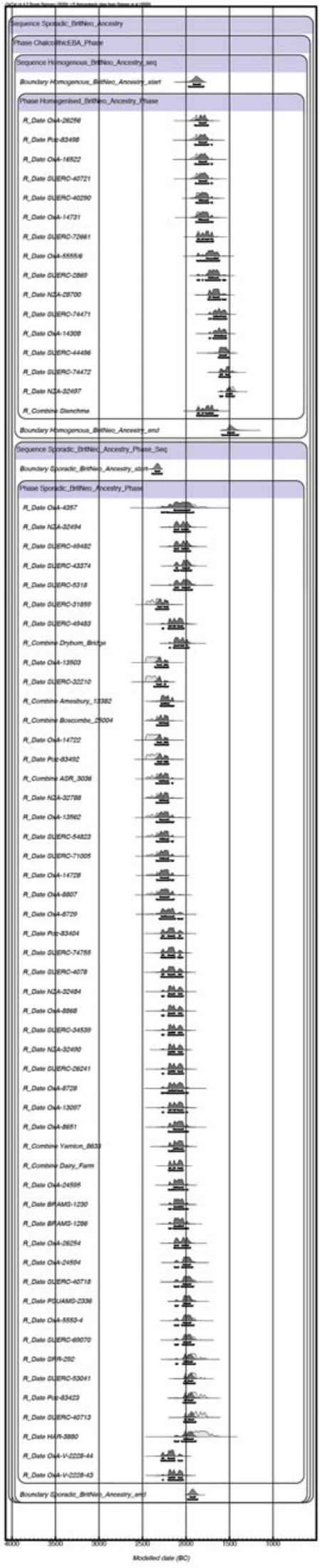

that is genetic relatives too distant to be recognized by the methods used by Olalde et al. (2018).

These results suggest that C-EBA people from particular families were treated in ways which were more visible archaeologically than other forms of mortuary practice. While ancestry can vary substantially between genetically related people, on average genetic relatives are more likely to have similar ancestry profiles (Huff et al. 2011). Therefore, biased patterns of genetic admixture in C-EBA Britain may be influenced not only by the underrepresentation of individuals carrying higher levels of ancestry from British Neolithic populations of Britain, but also the overrepresentation of individuals from particular families who carried higher levels of steppe-related continental ancestry. These families may have maintained higher levels of steppe-related continental ancestry through more intense marriage networks with populations in Britain and continental Europe who also predominantly carried this ancestry. Evidence of more dynamic interactions between populations with variable genetic affiliations to the Neolithic populations of Britain may be largely absent from the C-EBA funerary record.

The evidence for synchronicity of populations with variable genetic affiliations with the Neolithic population of Britain suggests the $>90$ per cent shift in the ancestry of C-EBA populations in Britain need not have been sudden. When we use OxCal 4.4 and the IntCal20 curve to model radiocarbon dates from C-EBA samples as two independent chronological phases, one including individuals who carry little-to-no or substantial ancestry related to Neolithic populations of Britain and another including individuals where ancestry related to Neolithic Britain has largely homogenized, the synchronicity of populations with diverse ancestries begins by $2387-2278$ cal. BC (95 per cent probability) and the $>90$ per cent genetic shift is complete by 1980-1869 cal. BC (95 per cent probability), taking 311-472 years (95 per cent probability) or 10-16 generations (Bronk Ramsey 2009; Reimer et al. 2020; Supplementary Table 3; Fig. 3). The maximum overlap between our two chronological phases is estimated at 145 years (95 per cent probability;

Figure 3. Chronological phase model for C-EBA samples showing very little (0-5 per cent) or substantial (20-40 per cent) ancestry related to Neolithic populations of Britain suggesting population synchronicity. (Generated in OxCal 4.4 using the IntCal20 Curve: see Supplementary Table 3; Bronk Ramsey 2009; Reimer et al. 2020.) 
Supplementary Table 3). Interpretations of social and cultural change in Chalcolithic Britain which lean on a rapid shift in ancestry, specifically those which invoke sudden large movements of people or catastrophic 'wipe-outs' of local populations through violence, disease, or both (Barras 2019; Kristiansen et al. 2017), are a weaker fit for the archaeogenetic evidence than those which involve longer-term factors.

The extension of the period over which this C-EBA genetic shift occurs moves the interpretive emphasis away from early impactful events onto factors affecting disparities in descendants over the longer term (Vander Linden 2016). This could have involved violence, although the osteological evidence suggests there was less interpersonal violence in this period in Britain compared to the Neolithic, and there is little evidence for endemic conflict (Armit 2011; Parker Pearson et al. 2019b; Thorpe 2006). Associations between ancestry and resistance to infectious diseases could have played a role, although suggestions that populations carrying steppe-related ancestry introduced plague (Yersinia pestis) into different regions of Europe in the third millennium $\mathrm{BC}$ are complicated by the detection of plague in human remains from Neolithic Scandinavia (Fuchs et al. 2019; Rascovan et al. 2019; Rasmussen et al. 2015). There is evidence for a Late Neolithic demographic decline in regions of Britain that could have contributed to a diminished genetic legacy (Colledge et al. 2019; Downey et al. 2016; Shennan et al. 2013; Stevens \& Fuller 2012; Timpson et al. 2014). Continuous C-EBA cross-Channel population movements over several centuries in the context of regular inter-community interaction could gradually have diluted ancestry related to the British Neolithic. Such a scenario clashes with the paucity of first-generation long-distance migrants identified by strontium and oxygen stable isotope analyses of tooth enamel to investigate individual mobility as part of the Beaker People project (Montgomery et al. 2019; Parker Pearson et al. 2016; Pellegrini et al. 2016; 2019). While only 16 of the 183 burials (9 per cent) which were subject to strontium and oxygen stable isotope analyses have associated DNA data reported in Olalde et al. (2018), samples from both studies are similarly distributed around Britain (see Parker Pearson et al. 2019a, fig. 1.1; Olalde et al. 2018, fig. 1a). Different lifestyles, access to resources and social practices which affect the chances of people having slightly more children who live to reproductive age could also help to account for differential genetic legacies over the long term (Thomas et al. 2006). This need not imply that incoming groups were socially or politically

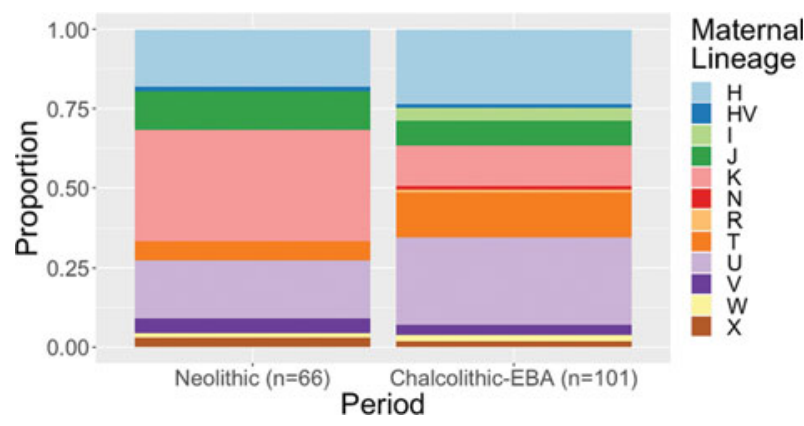

Figure 4. Proportional bar charts showing the proportions of maternal lineages (mitochondrial haplogroups) recorded in populations of Britain during the Chalcolithic-Bronze Age and the Neolithic.

dominant, however, and family size may reflect differences in ideology as much as economic or political success. The extent to which any of these explanations may explain the shift in ancestry we see in C-EBA Britain will have to be resolved through future archaeological and archaeogenetic analysis.

There has been no formal test of whether movements into C-EBA Britain were male-biased, although the shift in whole ancestry is accompanied by a 90 per cent replacement of paternal lineages (Olalde et al. 2018). Such a large-scale turnover of patrilineages certainly indicates that males were involved in population movements into Britain, and is somewhat consistent with Kristiansen et al.'s (2017) model of male-dominated migrations. However, novel maternal lineages also appear in Britain around the same time (Olalde et al. 2018), indicating that some women moved, too (Fig. 4). Overlaps in distributions of maternal lineages in different relevant populations and high diversity of maternal lineages in populations who preceded groups carrying steppe-related ancestry mean that it is currently difficult to define the scale of this change accurately. As we derive around 50 per cent of our DNA from each of our parents, Kristiansen et al.'s (2017) model of male migration and exogamy would predict an early pulse of genome-wide ancestry related to Neolithic populations (Furtwängler et al. 2020). However, such a pattern of admixture is not apparent in the current C-EBA sample set from Britain (see Furtwängler et al. 2020), with most samples, including some of the earliest dated examples, showing little or no ancestry related to populations of Neolithic Britain (Olalde et al. 2018).

Recent isotopic analysis of British Beaker burials also indicates that both men and women could be highly mobile over their lifetimes (Montgomery 
et al. 2019; Parker Pearson et al. 2016; Pellegrini et al. 2016). The earliest C-EBA individual with steppe-related continental ancestry identified by stable isotope analysis as a possible first-generation continental migrant (I5376, BPP Sk27 from Sorisdale, Coll, Scotland) was female (Parker Pearson et al. 2019b). No obvious differences in patterns of movement could be discerned, with men and women making both short and long journeys. In general, however, long-distance movement was much less common than the sorts of short journeys that might have resulted from activities such as following herds, gathering at sacred sites for seasonal ceremonies, or other common forms of intercommunity interaction, such as exchange and marriage. We cannot rule out that movements of people into Britain were generally male-biased, but currently the archaeogenetic evidence supports early movements of communities, including men and women, who largely had children among themselves.

As outlined by Parker Pearson et al. (2019b), these results correspond well with Needham's model for the development of Beaker-related social practices in Britain, whereby early incoming groups inhabited enclaves between sites of Neolithic settlement and largely (although far from exclusively) married among themselves and with communities in continental Europe (Needham 2005; 2012). The homogenization of ancestry from British Neolithic populations beginning around 2100 BC occurs just after Needham's 'Beaker fission' horizon, which entails a diversification of material culture and social practices, including some possible resurgence of Neolithic practices (Needham 2005; Parker Pearson et al. 2016). The fission horizon may reflect social change which facilitated more intensive intermarriage between groups with diverse genetic affiliations to populations of Neolithic Britain and continental Europe.

\section{Genetic relatedness in C-EBA Britain}

Archaeologists and archaeogeneticists are now just beginning to explore how the identification of closer genetic relationships between burials can illuminate kinship and marriage patterns, as well as mobility, admixture, social organization and funerary behaviour in the past (e.g. Cassidy et al. 2020; Furtwängler et al. 2020; Mittnik et al. 2019; Schroeder et al. 2019; Sjögren et al. 2020). Sixteen (22 per cent) of the 72 C-EBA burials examined by Olalde et al. (2018), including some of the close genetic relatives, have been subject to strontium and oxygen stable isotope analyses to investigate individual mobility (Montgomery et al. 2019; Parker Pearson et al. 2016; Pellegrini et al. 2016; 2019) providing additional detail on the origins and life-histories of particular individuals. It is beyond the scope of this paper to discuss all of the examples for which we have DNA and stable isotope data and instead we concentrate on examples where we also have patterns of genetic relatedness (Table 1).

To date, archaeological studies of kinship and marriage based on genetic evidence have tended to reproduce normative visions of gender and familial relationships derived from contemporary western experience (e.g. Haak et al. 2008; Mittnik et al. 2019; Schroeder et al. 2019; Sjögren et al. 2020) and that do not consider cross-cultural evidence for variability in the definition and organization of kinship. Anthropological studies of kinship indicate that kinship relations are not biogenetically determined but comprise socially structured links that are culturally constituted as natural facts (Schneider 1984; for overview, see Brück in press). Genetic and social paternity do not always coincide, for example, and people who are not genetically related may be viewed as kin (e.g. Evans-Pritchard 1951; Kahn 2000; Levine 2008). In many cultural contexts, kinship is not considered to be conferred at birth, but instead must be established and sustained through the sharing of food, co-residence and certain lifecycle rites (e.g. Carsten 1997; Vilaça 2002). The existence of genetic links, in other words, does not presuppose their social salience, and such relationships may not have been understood in ways that would be familiar within our own cultural context. The attribution of kinship can be contextually variable and strategically deployed, for example in order to claim relationships that facilitate access to important economic and political resources (e.g. Scheffler 1964). Although broad 'types' of kinship organization can be identified (e.g. patrilineality), their socio-political implications and the way these operate in practice differ significantly from society to society: gender ideologies and the position of women in patrilineal societies is highly variable, for example (Stone 2010). It is important to keep all of these points in mind as we consider the possible implications of the genetic relationships identified in the supplementary information of Olalde et al. (2018).

The most remarkable set of relatives reported by Olalde et al. (2018, supplementary table 1, column 14) were four individuals distributed across three cemeteries located within $10 \mathrm{~km}$ of the Stonehenge monument, close to the present-day village of Amesbury in Wiltshire (Fig. 5). The sites include the round barrow cemetery at Wilsford, the round barrow/pit grave 
cemeteries at Amesbury Down and the segmented ring-ditch cemetery at Porton Down (Andrews et al. 2016; Powell \& Barclay in press; Smith 1991).

A 17-25-year-old male (Inhumation 7) from Wilsford barrow G.54 was the 2nd-3rd degree genetic relative of two adult male burials (Burials 13382 and 13385) from Amesbury Down who were also 2nd-3rd degree relatives of one another. Radiocarbon dates from all three individuals are statistically indistinguishable (Ward \& Wilson 1978). These three men belonged to the same patrilineages but different matrilineages, suggesting they were probably paternal relatives. Amesbury Down Burial 13382 was also a 1st order genetic relative of a 20 23-year-old female (Burial 5108) recovered from the central burial group at Porton Down. This Porton Down burial was a 2nd-3rd degree relative of Inhumation 7 from Wilsford G.54, but was not identified as a relative of Burial 13385, indicating that they had a greater-than-third-order genetic relationship.

The simplest interpretation of these four genetic relatives is that the man from Wilsford G.54 (Inhumation 7) was the paternal uncle or grandfather of the two men buried near one another at Amesbury Down (13382 and 13385), who were paternal cousins. The Amesbury Down cousins were both buried near a Neolithic timber post setting, and it is probable that their genetic relatedness influenced their proximity. Amesbury 13382 was the father of the woman (5108) buried at Porton Down (Fig 5). These four people cover at least three generations of genetic relatives. None of these individuals had any substantial ancestry from populations who inhabited Britain during the Neolithic. Therefore, all unsampled individuals from this family tree with whom sampled individuals would have shared DNA must also have predominantly carried steppe-related continental ancestry. This pattern of ancestry is common among other groups of close genetic relatives identified here, and adds to the impression that communities of people carrying steppe-related continental ancestry moved into Britain during the C-EBA and largely had children among themselves. Yet the burials of the two paternal cousins on Amesbury Down near a Neolithic post setting demonstrates knowledge of and interest in earlier monuments and social practices.

Elsewhere on Amesbury Down, an articulated subadult male (Burial 5292) and an articulated adult male (Burial 5289) buried in adjacent pits were 1st degree relatives and shared a paternal but not a maternal lineage, indicating they were genetic father and son. The proximity of these two burials was probably informed by their genetic relatedness.
Another pair of significant relatives from Amesbury Down was identified from the so-called 'Boscombe Bowmen' grave, a collective burial of bones from at least nine people in an accessible wooden structure (Fitzpatrick 2011). Burial 25004, an articulated adult male skeleton accompanied by the incomplete disarticulated remains of five or six other people, was probably the paternal cousin or half-brother of an individual represented by a disarticulated cranium found at his feet (25005 - ON 10). Stable isotope analysis suggested that they were both non-local and had been on similar journeys in childhood (Evans et al. 2006; Fitzpatrick 2004; 2011). The genetic relationship between these two individuals means that it is tempting to suggest they moved together, perhaps as part of a larger group of kin.

Burial 25004 shows the highest levels of ancestry related to British Neolithic populations of any C-EBA sample from Britain, high enough to suggest that the ancestry of one of his parents was entirely derived from the Neolithic populations of Britain. This is a notable finding coming from a grave containing one of the best-known Beaker assemblages of grave goods from Britain (Fitzpatrick 2011), and undermines any absolute associations between ancestry and material culture. The paternal lineage of Burial 25004 (R1b) is absent from sampled Neolithic populations of Britain but present in 90 per cent of C-EBA males carrying steppe-related continental ancestry (Olalde et al. 2018). Therefore, it is more likely that it was his mother who shared significant genetic affinities with Neolithic populations, although it remains possible that he received substantial British Neolithic-related ancestry from both parents. Alternatively, appraisals of the stable isotope and archaeological evidence which place the origins of Burial 25004 outside of Britain (possibly Brittany-see Parker Pearson et al. 2019a, 13) may be explained in several different ways: Burial 25004 came from a population on continental Europe who carried lower levels of steppe-related ancestry; Burial 25004 was born in continental Europe to a mother who had substantial genetic ancestry from local Neolithic populations; or Burial 25004 was born in Britain but moved to continental Europe soon afterwards, before moving back to Britain later in life.

Indications that Burial 25004's mother had substantial ancestry related to the Neolithic population of Britain is somewhat consistent with the model proposed by Kristiansen et al. (2017) whereby migrations of people carrying steppe-related ancestry were characterized by incoming groups of men intermarrying with local women. However, as discussed above, 
Table 1. Results of genetic analyses, osteological assessments, stable isotope analyses and radiocarbon dating of Chalcolithic-Early Bronze Age genetic relatives identified by Olalde et al. (2018). Genetically unrelated individuals from the same site are also included (see Supplementary Table 2 for more details).

\begin{tabular}{|c|c|c|c|c|c|c|c|c|c|c|c|}
\hline ID & Site & Skeleton & $\begin{array}{l}\text { Age-at-death } \\
\text { (years) }\end{array}$ & Sex & $\begin{array}{l}\text { Radiocarbon } \\
\text { date } \\
\text { (cal. } \mathrm{BC}, 95 \% \\
\text { confidence) }\end{array}$ & $\begin{array}{l}\text { Steppe-related } \\
\text { continental } \\
\text { ancestry (\%) }\end{array}$ & $\begin{array}{c}\text { Ancestry } \\
\text { from } \\
\text { Neolithic } \\
\text { Britain (\%) }\end{array}$ & $\begin{array}{l}\text { Probable genetic } \\
\text { relationship }\end{array}$ & $\begin{array}{c}\text { Local } \\
\text { (Sr \& O } \\
\text { stable } \\
\text { isotopes) }\end{array}$ & $\begin{array}{c}\text { Possible } \\
\text { origin } \\
\text { (Sr \& O } \\
\text { stable } \\
\text { isotopes) }\end{array}$ & $\begin{array}{l}\text { Grave } \\
\text { goods }\end{array}$ \\
\hline I2459 & $\begin{array}{l}\text { Amesbury } \\
\text { Down }\end{array}$ & 62014 & 9-11 & $\mathrm{F}$ & $2453-2148$ & 100 & 0 & $\begin{array}{l}\text { Maternal aunt of } \\
62027 \\
\end{array}$ & - & - & No \\
\hline I2460 & $\begin{array}{l}\text { Amesbury } \\
\text { Down }\end{array}$ & 62027 & Adult & $\mathrm{F}$ & 2024-1782 & 100 & 0 & $\begin{array}{c}\text { Maternal niece of } \\
62014 \\
\end{array}$ & - & - & No \\
\hline I4951 & $\begin{array}{l}\text { Netheravon } \\
\text { Flying School }\end{array}$ & Burial 1 & Older adult & M & $2286-2045$ & 100 & 0 & $\begin{array}{l}\text { Paternal uncle or } \\
\text { grandfather of } \\
\text { Individual } 2\end{array}$ & Non-local & $\begin{array}{c}\text { Wales; } \\
\text { W } \\
\text { England; } \\
\text { Scotland; } \\
\text { Brittany }\end{array}$ & Yes \\
\hline I5512 & $\begin{array}{l}\text { Netheravon } \\
\text { Flying School }\end{array}$ & Burial 2 & Adult & $\mathrm{F}$ & 2204-2034 & 96 & 4 & $\begin{array}{l}\text { Paternal niece or } \\
\text { granddaughter of } \\
\text { Individual } 1\end{array}$ & Non-local & $\begin{array}{c}\text { SW } \\
\text { England }\end{array}$ & Yes \\
\hline I6777 & Wilsford G.54 & $\begin{array}{c}\text { Inhumation } \\
7\end{array}$ & $17-25$ & M & $2457-2206$ & 100 & 0 & $\begin{array}{l}\text { Paternal uncle or } \\
\text { grandfather of } \\
\text { Amesbury Down } \\
13382\end{array}$ & Non-local & $\begin{array}{c}\text { SW } \\
\text { England }\end{array}$ & Yes \\
\hline I2566 & $\begin{array}{l}\text { Amesbury } \\
\text { Down }\end{array}$ & 13385 & Adult & M & $2267-2036$ & 96 & 4 & $\begin{array}{c}\text { Paternal cousin of } \\
\text { Amesbury Down } \\
13382\end{array}$ & - & - & Yes \\
\hline I2600 & Porton Down & 5108 & $20-23$ & $\mathrm{~F}$ & 2135-1934 & - & - & $\begin{array}{c}\text { Daughter of } \\
\text { Amesbury Down } \\
13382\end{array}$ & - & - & No \\
\hline I2457 & $\begin{array}{l}\text { Amesbury } \\
\text { Down }\end{array}$ & 13382 & Adult & M & $2296-2142$ & 96 & 4 & $\begin{array}{l}\text { Father of Porton } \\
\text { Down } 5108\end{array}$ & - & - & No \\
\hline I2596 & $\begin{array}{l}\text { Amesbury } \\
\text { Down }\end{array}$ & 5289 & Adult & M & 2277-2035 & - & - & Father of 5292 & Non-local & $\begin{array}{l}\text { SW } \\
\text { England; } \\
\text { SE } \\
\text { England; } \\
\text { N England; } \\
\text { Scotland }\end{array}$ & No \\
\hline I2597 & $\begin{array}{l}\text { Amesbury } \\
\text { Down }\end{array}$ & 5292 & Subadult & M & $2276-2033$ & 99 & 1 & Son of 5289 & Local & - & No \\
\hline I 2443 & Yarnton & SK 8772 & $45+$ & $\mathrm{F}$ & 2277-2035 & 100 & 0 & $\begin{array}{l}\text { Paternal } \\
\text { grandmother or } \\
\text { great-aunt of } \\
\text { Sk } 8633\end{array}$ & - & - & No \\
\hline
\end{tabular}


Table 1. Continued

\begin{tabular}{|c|c|c|c|c|c|c|c|c|c|c|c|}
\hline ID & Site & Skeleton & $\begin{array}{c}\text { Age-at-death } \\
\text { (years) }\end{array}$ & Sex & $\begin{array}{l}\text { Radiocarbon } \\
\text { date } \\
\text { (cal. } \mathrm{BC}, 95 \% \\
\text { confidence) }\end{array}$ & $\begin{array}{l}\text { Steppe-related } \\
\text { continental } \\
\text { ancestry }(\%)\end{array}$ & $\begin{array}{c}\text { Ancestry } \\
\text { from } \\
\text { Neolithic } \\
\text { Britain (\%) }\end{array}$ & $\begin{array}{l}\text { Probable genetic } \\
\text { relationship }\end{array}$ & $\begin{array}{c}\text { Local } \\
\text { (Sr \& O } \\
\text { stable } \\
\text { isotopes) }\end{array}$ & $\begin{array}{c}\text { Possible } \\
\text { origin } \\
\text { (Sr \& O } \\
\text { stable } \\
\text { isotopes) } \\
\end{array}$ & $\begin{array}{l}\text { Grave } \\
\text { goods }\end{array}$ \\
\hline I3256 & $\begin{array}{l}\text { Trumpington } \\
\text { Meadows }\end{array}$ & $\begin{array}{c}\text { skeleton } \\
3384\end{array}$ & $17-20$ & M & 2269-2027 & 94 & 6 & $\begin{array}{r}\text { Maternal cousin or } \\
\text { half-brother of } 3383\end{array}$ & - & - & Yes \\
\hline I2417 & $\begin{array}{l}\text { Boscombe } \\
\text { Bowmen }\end{array}$ & ON 10 & Adult & M & $2467-2210$ & 100 & 0 & $\begin{array}{l}\text { Paternal cousin or } \\
\text { half-brother of } 25004\end{array}$ & Non-local & $\begin{array}{l}\text { Wales; } \\
\text { W } \\
\text { England; } \\
\text { Scotland; } \\
\text { Brittany }\end{array}$ & Yes \\
\hline I2416 & $\begin{array}{l}\text { Boscombe } \\
\text { Bowmen }\end{array}$ & 25004 & Adult & M & $2451-2201$ & 60 & 40 & $\begin{array}{l}\text { Paternal cousin or } \\
\text { half-brother of ON } \\
10\end{array}$ & Non-local & $\begin{array}{l}\text { Wales; } \\
\text { W } \\
\text { England; } \\
\text { Scotland; } \\
\text { Brittany }\end{array}$ & Yes \\
\hline I2446 & Yarnton & Sk 8784 & Adult & $\mathrm{F}$ & 2454-2139 & 91 & 9 & No relatives & - & - & No \\
\hline I2461 & Porton Down & 5117 & 6-9 months & $\mathrm{F}$ & & 97 & 3 & No relatives & - & - & Yes \\
\hline I2447 & Yarnton & SK 8779 & Neonate & $\mathrm{M}$ & 2120-1898 & 99 & 1 & No relatives & - & - & No \\
\hline I2565 & $\begin{array}{l}\text { Amesbury } \\
\text { Down }\end{array}$ & 1238 & $25-30$ & M & $2456-2146$ & 95 & 5 & No relatives & Local & - & Yes \\
\hline
\end{tabular}



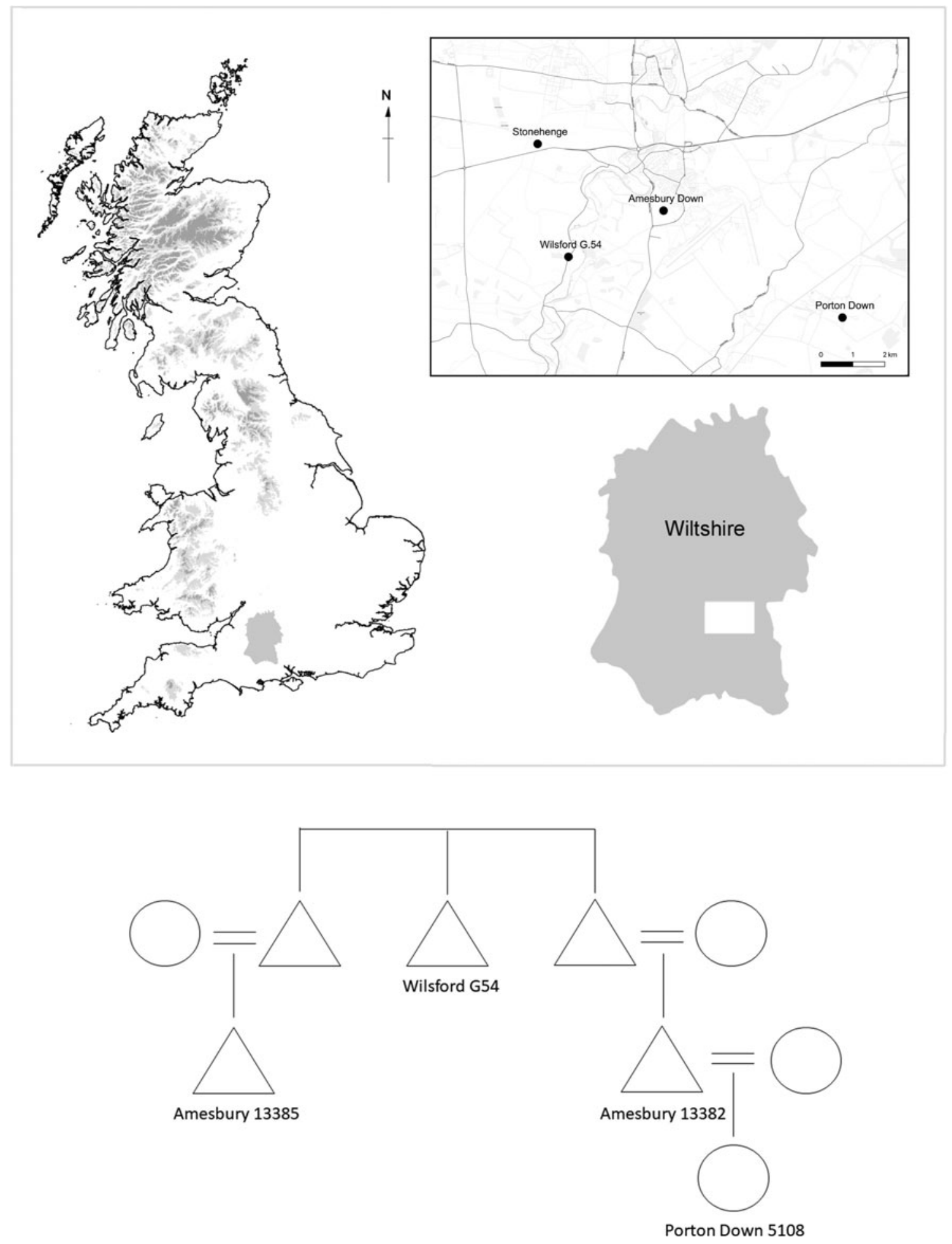

Figure 5. Probable genetic links between C-EBA burials distributed around present-day Amesbury.

the lack of evidence for an initial 'pulse' of admixture related to the Neolithic populations of Britain (Furtwängler et al. 2020) in the C-EBA sample from
Britain suggests that ancestry change was not solely or even predominantly driven by migrating males intermarrying with local females. 
The genetic relationship between Burial 25004 and cranium ON 10 suggests the wooden structure may have represented a place where members of an extended family were successively interred, or where a selection of remains from particular kin were redeposited alongside Burial 25004. The suggestion that both individuals had been on similar journeys, perhaps together, may have also influenced the decision to bury them together.

Recent archaeogenetic studies have integrated dense regional results with radiocarbon and stable isotope data to look at patterns of genetic relatedness, mobility and social organization in Corded Ware, Bell Beaker and Early Bronze Age societies in present-day southern Germany and Poland (Furtwängler et al. 2020; Mittnik et al. 2019; Sjögren et al. 2020). These studies assume that cemeteries served particular households/farmsteads and reflected cohabiting individuals/groups. There is some support for this from the Lech Valley, southern Germany, where cemeteries were associated with specific farmsteads. The data from these regions have been argued to indicate the importance of agnatic ties, a scarcity of adult female genetic relatives, female mobility, male residency and an absence of genetic half-siblings. These observations have been used to infer that communities were patrilocal, exogamous and monogamous, supporting ethnolinguistic reconstructions of early IndoEuropean societies (Sjögren et al. 2020). Female mobility is interpreted as movement for marriage, whereas male mobility is interpreted as migrating males founding new settlements or fostering of young males. Sex-specific interpretations of mobility, and the inference of fosterage systems specifically, are argued to be supported by stable isotope signatures showing that some males spent part of their childhood in one place before returning to the areas where they were buried (Mittnik et al. 2019; Sjögren et al. 2020). It is implied by Sjögren et al. 2020 that these social systems are likely to be present to some extent in all early Indo-European societies which developed out of movements of people carrying steppe-related ancestry.

It is evident from the genetic relationships identified in C-EBA Britain by Olalde et al. (2018) that paternal relations were important in C-EBA Britain (Sjögren et al. 2020). Ten of the individuals in the Olalde et al. (2018) dataset were paternally related to people buried in the same or neighbouring graves (Table 1), suggesting that patrilineal descent was a significant factor in the reckoning of social identity. There are some significant inconsistencies with proposed models for Bell Beaker societies, however.
The likely paternal uncle of the cousins 13382 and 13385 from Amesbury Down was himself buried in a different cemetery at Wilsford Down. C-EBA cemeteries in Britain are frequently interpreted as the burial grounds of individual descent groups, particularly because in many cases there is a linear element to the arrangement of graves that is thought to reflect genealogical succession (e.g. Garwood 1991). Here, however, close male genetic relatives were not buried in the same cemetery. So, too, four pairs of contemporary individuals from Amesbury Down were identified as close relatives, but each pair was genetically unrelated to all of the other pairs, undermining the assumption that C-EBA cemeteries represent the burial places of particular patrilineal descent groups and that ideas of kinship and descent were necessarily based on genetic links. Even in the small sample set discussed here, the same genetic relationships were not always expressed in the same ways in funerary treatment. The paternal cousins on Amesbury Down were buried as complete bodies in neighbouring graves, whereas at Boscombe Down only the skull belonging to the paternal cousin or half-brother of Burial 25004 was deposited together with him in the same grave. The timing, sequence and extent of the disturbance of the Boscombe Bowmen skeletons are uncertain (Fitzpatrick 2004), but taken at face value their positions suggest some variability in the articulation and significance of particular relationships and indicates that the role of genetic relatedness in informing funerary practice varied from burial to burial.

Anthropological studies of kinship demonstrate that even where there is patrilineal descent in principle, relationships with maternal kin continue to be highly important (e.g. Held 1957). Such relationships tend to be contextually deployed, though in some societies they can be formalized: certain things (land, cattle, goods, titles, etc.) may be passed via patrilineal and other things via matrilineal descent (Forde 1950). It is therefore no surprise that maternal relations were sometimes also foregrounded in C-EBA Britain. Although most of the genetic relatives from Amesbury Down and nearby sites were paternally related, maternal relations were evidently sometimes significant. The articulated skeleton of a 9-11-year-old female (Burial 62014) from Amesbury Down was placed in a cylindrical pit (Powell \& Barclay in press) adjacent to another pit containing an adult female cranium and atlas vertebra (Burial 62027). These two burials were 2 nd-3rd degree relatives and belonged to the same maternal lineage, but radiocarbon dating indicated that Burial 62014 had died before Burial 62027. The young age-at-death of 
Burial 62014 means that it is highly unlikely that she had children and therefore could not have been a direct maternal ancestor of Burial 62027. Burial 62014 was probably the genetic maternal aunt of Burial 62027. Putting aside the possibility of anomalous radiocarbon dating, this result suggests Burial 62014 and Burial 62027 may not have known each another in life, although their remains referenced one another in death.

Elsewhere, a young man and woman buried together in the same grave at Trumpington Meadows were 2nd-3rd degree relatives belonging to the same matrilineage (Evans et al. 2018). It is possible that matrilineal descent was the key principle of kinship organization in this community, hinting at regional variability in kinship structures. Radiocarbon dates on the remains of these two individuals are statistically indistinguishable (Ward \& Wilson 1978). They may have been half-siblings related through their mother. In matrilineal societies, a woman's loyalty is to her brother not her husband (Schneider 1961). Alternatively, they may have been the children of two sisters. Parallel cousins (the children of same-sex siblings) are regarded as siblings in many societies and marriage between them is prohibited (e.g. Busby 1997).

Although paternal links are the most common form of genetic relationship identified in the data, the identification of a patrilineal element to C-EBA descent does not indicate that women were insignificant social actors. There is considerable variability in the status of women in patrilineal societies (Stone 2010). Women often play essential roles in maintaining productive political and economic links between kin groups. Among the Nuer, for example, daughters are highly valued because they bring in bridewealth in the form of cattle that are used in turn to reproduce the patrilineage by finding wives for sons (Evans-Pritchard 1951). Nuer fatherhood is not predicated on sexual relations with the mother, but on the transfer of cattle in bridewealth transactions; this means that women's activities are not closely monitored or controlled by men.

In C-EBA Britain, the significance of women within patrilineal communities may be indicated by the presence of female inhumations in central positions within mortuary monuments, for example Burial 5108 at Porton Down. An older adult female buried on a wooden bier or in a wooden coffin in the entrance to a Neolithic enclosure at Yarnton (Sk 8784) was the probable paternal grandmother of a male infant (Burial 8633) who had been buried close by (Hey et al. 2016). This suggests that the position of women in ancestral genealogies may also have been important. Given both this person and her potential grandson show little or no significant ancestral affiliation with British Neolithic populations, these burials also add to the evidence for incoming communities maintaining an interest in monuments with which they had little genetic ancestral connection.

Although patrilineal descent was obviously an important organizing principle, marriage and residence patterns are more difficult to discern. The burial of paternally related individuals in close proximity, for example the paternal cousins and the father and son from Amesbury Down, or the paternal grandmother and infant from Yarnton, is suggestive of patrilocal residence patterns. The question is complicated, however, by the evidence for significant residential mobility during this period. The stable isotope analyses that are available for eight of the males and two of the females discussed here suggest that only two males spent their childhood in the area where they were buried (Amesbury Down 5289 and Amesbury 1238), one of whom (Burial 1238) was genetically unrelated to other burials (Montgomery et al. 2019; Parker Pearson et al. 2016; Pellegrini et al. 2016; 2019). In other words, there is no evidence that relatives who were buried together actually lived together during life. Five of the male non-locals had stable isotope samples taken from their second premolars and third molars to track mobility into adolescence. Only one of these individuals shows a back-and-forth movement that could be interpreted as consistent with fosterage (Amesbury Burial 5289; Montgomery et al. 2019; Supplementary Table 2). Another (Amesbury 1238) shows the opposite signature whereby he grew up in the area where he was buried before moving elsewhere during adolescence. Both females showed non-local isotopic signatures, although one of these individuals (Burial 2 from Netheravon Flying School) could have grown up only a short distance from where she was buried. These results are consistent with extensive stable isotope results from C-EBA Britain suggesting that females were only marginally more mobile than males (Montgomery et al. 2019; Parker Pearson et al. 2016; 2019b).

Male mobility in C-EBA Britain may have been driven mainly by fosterage and founding of new settlements, as has been suggested for Copper and Bronze Age sites in Central Europe (Mittnik et al. 2019; Sjögren et al. 2020), but presently there is no $a$ priori reason for sex-specific interpretations of individual mobility and there is a range of other possible explanations. The lack of recognizable settlements, the paucity of evidence for extensive cereal 
cultivation and the apparent economic and cultural significance of cattle hint that while agriculture played a larger role in C-EBA economies than in the Late Neolithic, mobile pastoralism was probably a core component of the economy in many parts of Britain (Brück 1999; Stevens \& Fuller 2012; Towers et al. 2011). In such a context, seasonal patterns of mobility are likely to have been a key component in the lifestyles of both men and women. In the early part of the period, large ceremonial monuments such as Stonehenge may also have continued to draw diverse communities for the duration of important rites and festivities (Madgwick et al. 2019), resulting in regular patterns of movement over the annual cycle. At Netheravon Flying School, Wiltshire (Cunnington 1929), Burials 1 and 2 (an older adult male and an adult female respectively) were identified as 2 nd-3rd degree genetic relatives. They did not share a maternal lineage and radiocarbon dates from both skeletons are statistically indistinguishable (Ward \& Wilson 1978), suggesting Burial 1 was probably a genetic paternal uncle or possibly grandfather of Burial 2. Stable isotope analysis suggests that they moved into the area, possibly from the same place (Montgomery et al. 2019). This is difficult to explain under the limited frameworks for mobility proposed for sites in continental Europe (Furtwängler et al. 2020; Mittnik et al. 2019; Sjögren et al. 2020); a pattern of patrilocal marriage would expect to see women moving away from their paternal kin. It is tempting to speculate that the Netheravon Flying School pair undertook their journey together which, like the Boscombe Bowmen, evokes movements of kin groups. The presence at Netheravon Flying School and Trumpington Meadows of older adolescent/ adult females buried with close male relatives does not fit with models of patrilocal marriage; women may not always have moved away from their natal groups on marriage.

Sjögren et al. (2020) use the observation that the daughter of Amesbury Burial 13382 was interred around $6.5 \mathrm{~km}$ away at Porton Down as evidence for regional female exogamy. However, this interpretation does not consider the unusual burial context of Porton Down, which was populated almost entirely by the remains of females and infants and clearly did not represent all members of a particular residential or kin group (Andrews \& Thompson 2016). The assumption that the location of burial indicates the location of residence is also undermined by evidence for the curation, circulation and redeposition of human remains during this period (Booth \& Brück 2020; Booth et al. 2015; Brück 2006; Fowler 2013). Not only were fragments of human bone redeposited with later internments, but evidence for mummification indicates that complete bodies could sometimes be curated. It is therefore possible that at least some of these stable isotope values reflect movement in death rather than life (Parker Pearson et al. 2019b).

The presence of a pair of possible half-siblings related through their father on Boscombe Down could be interpreted as evidence for polygamy, although alternatively these individuals may have been cousins. The only other possible half-siblings identified were the pair from Trumpington Meadows who were maternally related. Although specific patterns of marriage and co-residence may be difficult to discern, the genetic evidence suggests complex rather than elementary structures of marriage (Lévi-Strauss 1949). Elementary structures of marriage involve positive marriage rules specifying whom one must marry; cross-cousin marriage is common in many societies, for example. This results in reciprocal movement of marriage partners between a relatively small number of kin groups over the generations. In contrast, negative marriage rules specify whom one must not marry. This creates a much wider pool of potential marriage partners. We have noted above that the four paternally related individuals from Amesbury Down (13392 and 13385), Porton Down and Wilsford Down all belonged to different matrilineages, suggesting complex systems of marriage. A lack of prescriptive rules for marriage would have facilitated the creation of varied, expansive and strategic inter-group alliances that may have made particular sense in the context of high levels of residential mobility. This may also explain the significant variability in cultural practice between groups with steppe-related ancestry across Europe in general, as well as the evident openness of such groups to pre-existing local cultural traditions. Employing Lévi-Strauss's terminology does not require us to adopt other elements of his model, however: his argument that men exchanged their sisters in order to create inter-group alliances (Lévi-Strauss 1969) is challenged by the ethnographic evidence which illustrates that women commonly play an active role in arranging marriages (Carsten $2012,13)$. How far the possible patterns of cohabitation and social organization inferred from these sites are applicable to C-EBA societies as a whole may be questionable, however, especially given the evidence that these burials represent a small subsection of the population more likely to have been conferred exceptional burial practices in particular places regardless of where they lived and whom they lived with. 


\section{Notable non-genetic relationships}

At other sites, close spatial relationships between burials that likely reflected intimate interpersonal ties in life are not mirrored in the genetic data. In these cases, it is possible that kinship relationships were not determined by biological relatedness. Four individuals (Sk 2, Sk 4, Sk 7 and Sk 8) from Windmill Fields, Ingleby Barwick, North Yorkshire, were buried within a few metres of one another (Annis et al. 1997). Sk 2 and Sk 7 comprised articulated single burials of an adult male and an adult female. Sk 4 was a disarticulated adult male cranium excavated from a collective deposit of disarticulated bones in a wooden cist. Sk 8 comprised a disarticulated adult female cranium that formed part of deposit of disarticulated crania and long bones accompanying an articulated adult female burial (Sk 6, which was not subject to archaeogenetic analysis). Their radiocarbon dates suggest they were broadly contemporary, but none of them were close genetic relatives. It is possible that these burials represent cryptic genetic kin, although the probability of this is reduced given that they all belong to different paternal and maternal lineages. Notably Sk 2 belonged to a paternal lineage that was ubiquitous in males who lived in Britain during the Neolithic (I2a), but uncommon (present at a rate of $\sim 10$ per cent) among C-EBA males carrying steppe-related continental ancestry. Sk 2 also carries substantial (26 per cent) levels of ancestry related to Neolithic populations, suggesting that he had a direct paternal relative, possibly a grandfather, whose ancestry could have come entirely from British Neolithic populations. It seems highly likely that the individuals buried at Windmill Fields belonged to a single community and that they may have viewed each other as kin. The absence of genetic relationships between adult male burials at Windmill Fields conflicts not only with ideas that kinship was determined by biological relatedness, but also patrilocal models of kinship proposed for other Bronze Age societies in Europe, and the probability that Sk 2 had a recent direct male paternal ancestor whose ancestry was mostly or completely derived from the Neolithic populations of Britain contradicts arguments that see incoming men marrying local women: in this case, it was a man with 'local' ancestry from the Neolithic who married a woman with steppe-related continental ancestry.

At Windmill Fields, co-residence may have determined kinship, as is common in many contemporary societies (e.g. Schneider 1984). Likewise, at Dryburn Bridge, East Lothian, two stone cists (Cist
1 and Cist 2) c. $10 \mathrm{~m}$ apart each contained the crouched inhumation burial of an adult male; both bodies had been laid on their left-hand sides (Dunwell 2007). The disarticulated skull and long bones of a second adult male had been placed at the hips of the skeleton in Cist 1 , while the same disarticulated elements from a 6-8-year-old child were deposited at the hips of the Cist 2 skeleton. The two articulated individuals had died around the same time (Ward \& Wilson 1978) but were not genetic relatives (Olalde et al. 2018). Twenty-five per cent of the ancestry of the male from Cist 2 could be attributed to Neolithic groups, suggesting he may have had a grandparent whose ancestry was entirely derived from the Neolithic population of Britain.

Notable similarities in the mortuary rites afforded to the two inhumation burials from Dryburn Bridge, as well as their spatial propinquity, suggest a strong shared sense of identity; as at Windmill Fields, they may have considered themselves to be kin even though they were not genetically related and had variable recent ancestral histories. Smaller bones were missing from the deposits of disarticulated bone, which were not subject to aDNA analysis, suggesting that these remains had been retrieved for reburial from elsewhere. The radiocarbon dates from the disarticulated burials and the articulated bodies they accompanied were statistically indistinguishable (Ward \& Wilson 1978). It seems highly likely, therefore, that the disarticulated remains derived from known individuals, probably viewed as kin, regardless of whether or not those relationships were based on genetic links (Booth \& Brück 2020).

The presence of non-related individuals requires us to consider forms of kinship that may not have been based solely on sexual procreation. Co-residence is likely to have been an important basis of kinship in many cases, but elsewhere, kinship relations may have been created and maintained via other forms of social practice. We have noted, for example, that there was a substantial number of individuals who were not genetically related to one another in the cemetery at Amesbury Down. In this case, a shared sense of identity may have been based on communal participation in ritual. The longstanding ceremonial significance of the Stonehenge landscape had, for generations, drawn people to it from far around (Madgwick et al. 2019), and it may be that inter-group links were framed in terms of common descent from mythic ancestors. It is interesting to note that individuals without evident genetic links to others in the same cemetery could be treated 
as significant kin. The partially articulated burial of an adult woman (Burial 6033) from Amesbury Down was revisited not long after she died (Gibson 2013). The grave was recut to facilitate the removal of some bones and the rearrangement of others. Similar practices have been well documented elsewhere and are interpreted as a means of engaging with and retrieving ancestral remains for curation and redeposition (Booth \& Brück 2020). Yet this individual had no genetic links to any of the others sampled from this or other nearby cemeteries. It should be noted, too, that this significant ancestor was female.

At other sites, the lack of evident genetic links between burials that have been deliberately placed in close proximity raises different and equally interesting questions. At Needingworth Quarry, Cambridgeshire, an adult female aged $18-25$ years was laid on her right side at the base of a deep grave. The grave was subsequently recut and a second adult female more than 40 years old was interred. Their deaths were not many years apart, but they were not genetically closely related. It is possible that they were co-wives in a polygamous marriage, but there are other explanations too. Historically, woman-to-woman marriage was widespread in Africa (Levine 2008, 378). A woman presumed to be barren could divorce her husband and remain in her father's home. She could herself then marry a woman whose children would count her as their father and who would be members of her patrilineage. Woman-to-woman marriage enhanced women's status and offered greater social and sexual freedom. A relationship of this sort could explain the spatial and social proximity of the women from Needingworth Quarry. Alternatively, friendship is another form of intimate relationship that may be reflected in this burial. The fascination shown by British anthropologists working in the first half of the twentieth century with patterns of kinship must be viewed as a reflection of their own location in a society where economic and social position were traced through lines of descent (Levine 2008). This means that kinship relations have been given particular prominence in anthropological accounts, often to the detriment of other important social ties.

In southern Germany, it has been argued that individuals who were not genetically related to others in the same cemetery were low-status outsiders and perhaps even slaves (Mittnik et al. 2019). This does not appear to have been the case in Britain. Three of the four individuals from Amesbury Down and neighbouring cemeteries who were not genetically linked to others in this area were buried with grave goods. In contrast, grave goods accompanied six out of ten of the individuals who had genetic relatives in the same or nearby cemeteries. There is no clear distinction in terms of possible status between individuals who can be assigned to a particular genetic kin group and those who cannot.

\section{Conclusion}

We have shown just how much detailed information can be gleaned from the supplementary information associated with large-scale archaeogenetic studies without the application of additional specific expertise in molecular biology or bioinformatics. We have showcased how it is possible to synthesize information on admixture and genetic relatedness presented in the supplementary information of Olalde et al. (2018) with various types of archaeological data to build more diverse and reflexive narratives of ancestry change in C-EBA Britain.

Our assessment suggests C-EBA individuals sampled by Olalde et al. (2018) tend to come from groups, including a high proportion of close genetic relatives, with overwhelming genetic affinities to populations who lived in proximal parts of continental Europe. However, there is evidence for the persistence of C-EBA groups more related to Neolithic populations who may be underrepresented in the current archaeogenetic dataset, possibly because they continued to cremate their dead and/or practise funerary rites which leave no archaeological trace (Parker Pearson et al. 2019b). This does not contradict the $>90$ per cent turnover in ancestry we see in C-EBA Britain, but emphasizes that the turnover process involved a prolonged period of integration, possibly taking place over as many as 16 generations. This result questions interpretations of ancestry turnover which assume it was rapid and necessarily involved a wipe-out of the local populations, and favours longer-term processes producing disparities in descendants. While we cannot rule out that population movements into Britain were male-biased, the current archaeogenetic evidence is more consistent with movements of communities including men and women.

Analysis of genetic relatedness and stable isotopes provides little support for Beaker societies in Britain as strictly patrilocal or practising female exogamy, although paternal links were clearly often important. Biomolecular analysis of further samples might provide more support for patrilocality and exogamy, but results discussed here highlight that it is hazardous to assume that all societies influenced 
by movements of people who carried steppe-related ancestry operated in the same way. Interpretations of genetic change and kinship need to be considered alongside contextual archaeological evidence and underpinned by critical perspectives on kinship and identity as social phenomena rather than natural facts. Indeed, the evidence presented here hints at significant variability in how ties based on sexual procreation were ascribed social value and how particular relationships (for example between men and women) were organized. Although there is clear evidence for mobility during this period, relatively few individuals appear to have moved over long distances (Parker Pearson et al. 2019a), and a range of different social and economic activities may have resulted in regular inter-group contacts that contributed to genetic and cultural change over the long term.

\section{Acknowledgements}

We are very grateful to the two anonymous reviewers whose constructive criticisms led to a substantial improvement in the quality of our paper. Thanks to Andrew Fitzpatrick for providing some early feedback. TB is grateful to the attendees of the 2019 Bronze Age Forum in Durham, as well as Barry Cunliffe for convincing him that this paper was worth writing. This research was funded in whole, or in part, by the Wellcome Trust [Grant number 100713/Z/12/Z]. For the purpose of open access, the author has applied a CC BY public copyright licence to any Author Accepted Manuscript version arising from this submission.

\section{Supplementary material}

Supplementary Tables 1, $2 \& 3$ may be found at https://doi.org/10. 1017/S0959774321000019

\author{
Belfield \\ Dublin 4 \\ Ireland \\ Email: joanna.bruck@ucd.ac.ie \\ Selina Brace \\ Natural History Museum \\ Cromwell Road \\ London SW7 5BD \\ $U K$ \\ Email:s.brace@nhm.ac.uk \\ Ian Barnes \\ Natural History Museum \\ Cromwell Road \\ London SW7 5BD \\ UK \\ Email:i.barnes@nhm.ac.uk
}

\section{References}

Allentoft, M.E., M. Sikora, K.G. Sjögren, et al., 2015. Population genomics of Bronze Age Eurasia. Nature 522(7555), 167-72.

Andrews, P. \& S. Thompson, 2016. An Early Beaker funerary monument at Porton Down, Wiltshire. Wiltshire Archaeological and Natural History Magazine 109, 71-4.

Annis, R., S. Anderson, A. Bayliss, et al., 1997. An Unusual Group of Early Bronze Age Burials from Windmill Fields, Ingleby Barwick, Stockton-on-Tees. Unpublished report, Tees Archaeology.

Appleby, J., 2013. Temporality and the transition to cremation in the late third millennium to mid second millennium BC in Britain. Cambridge Archaeological Journal 23(1), 83-7.

Armit, I., 2011. Violence and society in the deep human past. British Journal of Criminology 51(3), 499-517.

Barras, C., 2019. History of violence. New Scientist 241 (3223), 29-33.

Bloxam, A., 2019. The Other Beaker People: Funerary Diversity in Britain, c. 2450-1950 BC. PhD thesis, University College London.

Bollongino, R., O. Nehlich, M.P. Richards, et al., 2013. 2000 years of parallel societies in Stone Age central Europe. Science 342(6157), 479-81.

Booth, T.J. \& J. Brück, 2020. Death is not the end: radiocarbon and histo-taphonomic evidence for curation and excarnation of human remains in Bronze Age Britain. Antiquity 94, 1186-1203.

Natural History Museum

Cromwell Road

London SW7 5BD

$U K$

Email: thomas.booth@crick.ac.uk

Joanna Brück

School of Archaeology

University College Dublin
Booth, T.J., A.T. Chamberlain \& M. Parker Pearson, 2015. Mummification in Bronze Age Britain. Antiquity 89, 1155-73.

Bronk Ramsey, C., 2009. Bayesian analysis of radiocarbon dates. Radiocarbon 51(1), 337-60.

Brück, J., 1999. What's in a settlement? Domestic practice and residential mobility in Early Bronze Age southern England, in Making Places in the Prehistoric 
World: Themes in settlement archaeology, eds J. Brück \& M. Goodman. London: UCL Press, 53-75.

Brück, J., 2006. Death, exchange and reproduction in the British Bronze Age. European Journal of Archaeology 9(1), 73-101.

Brück, J., in press. Ancient DNA, kinship and relational identities in Bronze Age Britain. Antiquity.

Brunel, S., E.A. Bennett, L. Cardin, et al., 2020. Ancient genomes from present-day France unveil 7,000 years of its demographic history. Proceedings of the National Academy of Sciences 117(23), 12791-8.

Busby, C., 1997. Of marriage and marriageability: gender and Dravidian kinship. Journal of the Royal Anthropological Institute 3, 261-78.

Cassidy, L.M., R.Ó. Maoldúin, T. Kador, et al., 2020. A dynastic elite in monumental Neolithic society. Nature 582(7812), 384-8.

Carlin, N., 2018. The Beaker Phenomenon? Understanding the character and context of social practices in Ireland 2500 2000 BC. Leiden: Sidestone.

Carsten, J., 1997. The Heat of the Hearth: The process of kinship in a Malay fishing community. Oxford: Clarendon Press.

Carsten, J., 2012. After Kinship. Cambridge: Cambridge University Press.

Cleal, R. \& J. Pollard, 2012. The revenge of the native: monuments, material culture, burial and other practices in the third quarter of the 3rd millennium BC in Wessex, in Is There a British Chalcolithic? People, place and polity in the late 3rd millennium BC, eds M. Allen, J. Gardiner \& A. Sheridan. Oxford: Oxbow, 317-32.

Colledge, S., J. Connolly, E. Crema \& S. Shennan, 2019. Neolithic population crash in northwest Europe associated with agricultural crisis. Quaternary Research 92(3), 686-707.

Cummings, V., 2017. The Neolithic of Britain and Ireland. London: Routledge.

Cunnington, M.E., 1929. Two Bronze Age Beaker burials at Netheravon. Wiltshire Archaeological and Natural History Magazine 53, 490-92.

Downey, S.S., W.R. Haas \& S.J. Shennan, 2016. European Neolithic societies showed early warning signals of population collapse. Proceedings of the National Academy of Sciences 113(35), 9751-6.

Drenth, E., 2014. Cremation graves of the Bell Beaker Culture from the Netherlands, in Around the Petit-Chasseur Site in Sion (Valais, Switzerland) and New Approaches to the Bell Beaker Culture, ed. M. Besse. Oxford: Archaeopress, 307-18.

Dunwell, A., 2007. Cist Burials and an Iron Age Settlement at Dryburn Bridge, Innerwick, East Lothian. (Scottish Archaeological Internet Reports 24.) Edinburgh: Society of Antiquaries of Scotland.

Evans, C., S. Lucy \& R. Patten, 2018. Riversides: Neolithic barrows, a Beaker grave, Iron Age and Anglo-Saxon burials and settlement at Trumpington, Cambridge. Cambridge: McDonald Institute for Archaeological Research.
Evans, J.A., C.A. Chenery \& A.P. Fitzpatrick, 2006. Bronze Age childhood migration of individuals near Stonehenge, revealed by strontium and oxygen isotope tooth enamel analysis. Archaeometry 48(2), 309-21.

Evans-Pritchard, E., 1951. Kinship and Marriage amongst the Nuer. Oxford: Oxford University Press.

Fernandes, D.M., A. Mittnik, I. Olalde, et al., 2020. The spread of steppe and Iranian-related ancestry in the islands of the western Mediterranean. Nature Ecology E Evolution 4(3), 334-5.

Fitzpatrick, A.P., 2004. The Boscombe bowmen: builders of Stonehenge. Current Archaeology 193, 10-16.

Fitzpatrick, A.P., 2011. The Amesbury Archer and the Boscombe Bowmen: Early Bell Beaker burials at Boscombe Down, Amesbury, Wiltshire, Great Britain: Excavations at Boscombe Down. Salisbury: Wessex Archaeology.

Fokkens, H., B. Veselka, Q. Bourgeois, I. Olalde \& D. Reich, 2017. Excavations of Late Neolithic arable, burial mounds and a number of well-preserved skeletons at Oostwoud-Tuithoorn: a re-analysis of old data. Analecta Praehistorica Leidensia 47, 95-150.

Forde, D., 1950. Double descent among the Yakö', in African Systems of Kinship and Marriage, eds. R. Radcliffe-Brown \& D. Forde. London: Oxford University Press, 285-332.

Fowler, C., 2013. The Emergent Past: A relational realist archaeology of Early Bronze Age mortuary practices. Oxford: Oxford University Press.

Frieman, C.J. \& D. Hofmann, 2019. Present pasts in the archaeology of genetics, identity, and migration in Europe: a critical essay. World Archaeology 58, 528-45.

Frieman, C.J., A. Teather \& C. Morgan, 2019. Bodies in motion: narratives and counter narratives of gendered mobility in European later prehistory. Norwegian Archaeological Review 52, 148-69.

Fuchs, K., C. Rinne, C. Drummer, A. Immel, B. Krause-Kyora \& A. Nebel, 2019. Infectious diseases and Neolithic transformations: evaluating biological and archaeological proxies in the German loess zone between 5500 and 2500 BCE. Holocene 29(10), 1545-57.

Furholt, M., 2018. Massive migrations? The impact of Recent aDNA studies on our view of third millennium Europe. European Journal of Archaeology 21(2), 159-91.

Furholt, M., 2019. Re-integrating archaeology: a contribution to aDNA studies and the migration discourse on the 3rd millennium BC in Europe. Proceedings of the Prehistoric Society 85, 1-15.

Furtwängler, A., A.B. Rohrlach, T.C. Lamnidis, et al., 2020. Ancient genomes reveal social and genetic structure of Late Neolithic Switzerland. Nature Communications 11(1), 1915.

Garwood, P., 1991. Ritual tradition and the reconstitution of society, in Sacred and Profane: Proceedings of a conference on Archaeology, Ritual and Religion, Oxford, 1989, eds. P. Garwood, D. Jennings, R. Skeates \& J. Toms. Oxford: Oxford University Committee for Archaeology, 10-32. 
Gibson, A.M., 1982. Beaker Domestic Sites: A study of the domestic pottery of the late $3 r d$ and early 2 nd millennia $B C$ in the British Isles. (BAR British series 107.) Oxford: British Archaeological Reports.

Gibson, C., 2013. Out of time but not out of place. Tempo, rhythm and dynamics of inhabitation in southern England, in Memory, Myth and Long-term Landscape Inhabitation, eds A. Chadwick \& C. Gibson. Oxford: Oxbow, 99-123.

Haak, W., G. Brandt, H.N. de Jong, et al., 2008. Ancient DNA, Strontium isotopes, and osteological analyses shed light on social and kinship organization of the Later Stone Age. Proceedings of the National Academy of Sciences 105(47), 18226-31.

Haak, W., I. Lazaridis, N. Patterson, et al., 2015. Massive migration from the steppe was a source for Indo-European languages in Europe. Nature 522 (7555), 207-11.

Hakenbeck, S.E., 2019. Genetics, archaeology and the far right: an unholy Trinity. World Archaeology 51, 517-27.

Held, D., 1957. The Papuans of Waropen. The Hague: Nijhoff.

Hey, G., C. Bell, C. Dennis \& M. Robinson, 2016. Yarnton: Neolithic and Bronze Age settlement and landscape: Results of excavations 1990-98. Oxford: Oxford University School of Archaeology.

Huff, C.D., D.J. Witherspoon, T.S. Simonson, et al., 2011. Maximum-likelihood estimation of recent shared ancestry (ERSA). Genome Research 21(5), 768-74.

Kahn, S., 2000. Reproducing Jews: A cultural account of assisted conception in Israel. Durham (NC): Duke University Press.

Knipper, C., A. Mittnik, K. Massy, et al., 2017. Female exogamy and gene pool diversification at the transition from the Final Neolithic to the Early Bronze Age in central Europe. Proceedings of the National Academy of Sciences Sep 2017, 201706355. DOI: 10.1073/ pnas.1706355114

Kristiansen, K., M.E. Allentoft, K.M. Frei, et al., 2017. Re-theorising mobility and the formation of culture and language among the Corded Ware Culture in Europe. Antiquity 91, 334-47.

Kuhn, J.M.M., M. Jakobsson \& T. Günther, 2018. Estimating genetic kin relationships in prehistoric populations. PLoS One. DOI: 10.1371/journal.pone.0195491

Lévi-Strauss, C., 1949. La politique étrangère d'une société primitive [Foreign policy of a primitive society]. Politique étrangère 14(2), 139-52.

Lévi-Strauss, C., 1969. The Elementary Structures of Kinship. Boston (MA): Beacon Press.

Levine, N.E, 2008. Alternative kinship, marriage, and reproduction. Annual Review of Anthropology 37, 375-89.

Linderholm, A., G. Merve Kılınç, A. Szczepanek, et al., 2020. Corded Ware cultural complexity uncovered using genomic and isotopic analysis from southeastern Poland. Nature Scientific Reports 10(1), 6885.

Lipson, M., A. Szécsényi-Nagy, S. Mallick, et al., 2017. Parallel palaeogenomic transects reveal complex genetic history of early European farmers. Nature 551(7680), 368-72.

Madgwick, R., A. Lamb, H. Sloane, A. Nederbragt, U. Albarella, M. Parker Pearson \& J. Evans, 2019. Multi-isotope analysis reveals that feasts in the Stonehenge environs and across Wessex drew people and animals from throughout Britain. Science Advances 5(3), eaau6078.

Mathieson, I., S. Alpaslan-Roodenberg, C. Posth, et al., 2018. The genomic history of southeastern Europe. Nature 555(7695), 197-203.

Mittnik, A., K. Massy, C. Knipper, et al., 2019. Kinshipbased social inequality in Bronze Age Europe. Science 366(6466), 731-4.

Montgomery, J., J. Evans \& J. Towers, 2019. Strontium isotope analysis, in The Beaker People: Isotopes, mobility and diet, eds M. Parker Pearson, A. Sheridan, M. Jay, A Chamberlain, M.P. Richards \& J. Evans. Oxford: Oxbow, 369-406.

Narasimhan, V.M., N. Patterson, P. Moorjani, et al., 2019. The formation of human populations in South and Central Asia. Science 365(6457), eaat7487.

Needham, S, 2005. Transforming Beaker culture in northwest Europe: processes of fusion and fission. Proceedings of the Prehistoric Society 71, 171-217.

Needham, S, 2012. Case and place for the British Chalcolithic, in Is There a British Chalcolithic? People, place and polity in the late 3rd millennium BC, eds M. Allen, J. Gardiner \& A. Sheridan. Oxford: Oxbow, 1-26.

Olalde, I., S. Brace, M.E. Allentoft, et al., 2018. The Beaker phenomenon and the genomic transformation of northwest Europe. Nature 555(7695), 190-96.

Olalde, I., S. Mallick, N. Patterson, et al., 2019. The genomic history of the Iberian Peninsula over the past 8000 years. Science 363(6432), 1230-34.

Parker Pearson, M., A. Chamberlain, M. Jay, et al., 2016. Beaker people in Britain: migration, mobility and diet. Antiquity 90, 620-37.

Parker Pearson, M., J.A. Sheridan, M. Jay, A. Chamberlain, M.P. Richards \& J. Evans, 2019a. The Beaker People Project individuals, their funerary practices and their grave goods, in The Beaker People: Isotopes, mobility and diet, eds M. Parker Pearson, A. Sheridan, M. Jay, A. Chamberlain, M.P. Richards \& J. Evans. Oxford: Oxbow, 115-210.

Parker Pearson, M., J.A. Sheridan, M. Jay, A. Chamberlain, M.P. Richards, \& J. Evans, 2019b. Synthesis, discussion and conclusions, in The Beaker People: Isotopes, mobility and diet, eds M. Parker Pearson, A. Sheridan, M. Jay, A. Chamberlain, M.P. Richards \& J. Evans. Oxford: Oxbow, 425-60.

Pellegrini, M., M. Jay, \& M.P. Richards, 2019. Oxygen isotope analysis, in The Beaker People: Isotopes, mobility and diet, eds M. Parker Pearson, A. Sheridan, M. Jay, A Chamberlain, M.P. Richards \& J. Evans. Oxford: Oxbow, 407-24.

Pellegrini, M., J. Pouncett, M. Jay, M. Parker Pearson \& M. P. Richards, 2016. Tooth enamel oxygen 'isoscapes' 
show a high degree of human mobility in prehistoric Britain. Scientific Reports 6(1), 34986.

Powell, A.B. \& A.J. Barclay, in press. Between and Beyond the Monuments: Prehistoric activity on the downlands southeast of Amesbury, Wiltshire. Salisbury: Wessex Archaeology.

Price, T.D., C. Knipper, G. Grupe \& V. Smrcka, 2004. Strontium isotopes and prehistoric human migration: the Bell Beaker period in Central Europe. European Journal of Archaeology 7(1), 9-40.

Rascovan, N., K.-G. Sjögren, K. Kristiansen, R. Nielsen, E. Willerslev, C. Desnues \& S. Rasmussen, 2019. Emergence and spread of basal lineages of Yersinia pestis during the Neolithic decline. Cell 176(1-2), 295-305.e10.

Rasmussen, S., M.E. Allentoft, K. Nielsen, et al., 2015. Early divergent strains of Yersinia pestis in Eurasia 5,000 years ago. Cell 163(3), 571-82.

Reimer, P.J., W.E.N. Austin, E. Bard, et al., 2020. The IntCal20 northern hemisphere radiocarbon age calibration curve (0-55 cal kBP). Radiocarbon 64(4), 725-57.

Rivollat, M., C. Jeong, S. Schiffels, et al., 2020. Ancient genome-wide DNA from France highlights the complexity of interactions between Mesolithic hunter-gatherers and Neolithic farmers. Science Advances 6(22), eaaz5344.

RStudio Team, 2020. RStudio: Integrated Development for $R$. Boston (MA): RStudio, PBC. http://www.rstudio.com/

Scheffler, H., 1964. Descent concepts and descent groups: the Maori case. Journal of the Polynesian Society 73, 126-33.

Schneider, D., 1961. Introduction: the distinctive features of matrilineal descent groups, in Matrilineal Kinship, eds D. Schneider \& K. Gough. Berkeley (CA): University of California Press, 1-29.

Schneider, D., 1984. A Critique of the Study of Kinship. Ann Arbor (MI): University of Michigan Press.

Schroeder, H., A. Margaryan, M. Szmyt, et al., 2019. Unraveling ancestry, kinship, and violence in a Late Neolithic mass grave. Proceedings of the National Academy of Sciences 116(22), 10705-10.

Shennan, S., S.S. Downey, A. Timpson, et al., 2013. Regional population collapse followed initial agriculture booms in mid-Holocene Europe. Nature Communications 4, 1-8.

Sjögren, K.-G., I. Olalde, S. Carver, et al., 2020. Kinship and social organization in Copper Age Europe. A crossdisciplinary analysis of archaeology, DNA, isotopes, and anthropology from two Bell Beaker cemeteries. PLoS One 15(11), e0241278.

Skoglund, P. \& I. Mathieson, 2018. Ancient genomics of modern humans: the first decade. Annual Review of Genomics and Human Genetics 19, 381-404.

Smith, I.F., 1991. Round barrows Wilsford cum Lake G51-G54: excavations by Ernest Greenfield in 1958. Wiltshire Archaeological and Natural History Magazine 84, 11-39.
Stevens, C.J. \& D.Q Fuller, 2012. Did Neolithic farming fail? The case for a Bronze Age agricultural revolution in the British Isles. Antiquity 86, 707-22.

Stone, L., 2010. Kinship and Gender: An introduction. Philadelphia (PA): Westview Press.

Thomas, M.G., M.P.H. Stumpf \& H. Härke, 2006. Evidence for an apartheid-like social structure in early Anglo-Saxon England. Proceedings of the Royal Society B: Biological Sciences 273(1601), 2651-7.

Thorpe, I.J.N., 2006. Fighting and feuding in Neolithic and Bronze Age Britain and Ireland, in Warfare and Society: Archaeological and social anthropological perspectives, eds T. Otto, H. Thrane \& H. Vandkilde. Aarhus: Aarhus University Press, 141-65.

Timpson, A., S. Colledge, E. Crema, et al., 2014. Reconstructing regional population fluctuations in the European Neolithic using radiocarbon dates: a new case-study using an improved method. Journal of Archaeological Science 52, 549-57.

Towers, J., M. Jay, I. Mainland, O. Nehlich \& J. Montgomery, 2011. A calf for all seasons? The potential of stable isotope analysis to investigate prehistoric husbandry practices. Journal of Archaeological Science 38, 1858-68.

Turek, J., 2008. Significance of cremation in the funerary practices of the Bell Beaker Eastern provinces, in Bell Beaker in Everyday Life, eds M. Baioni, V. Leonini, D. Lo Vetro, F. Martini, R. Poggiani Keller \& L. Sarti. Florence: Millenni, 271-9.

Vai, S., C.E.G. Amorim, M. Lari \& D. Caramelli, 2020. Kinship determination in archeological contexts through DNA analysis. Frontiers in Ecology and Evolution 8, 83.

Vander Linden, M., 2016. Population history in third-millennium-BC Europe: assessing the contribution of genetics. World Archaeology 48(5), 714-28.

Vilaça, A., 2002. Making kin out of others in Amazonia. Journal of the Royal Anthropological Institute 8(2), 347-65.

Wang, C.-C., S. Reinhold, A. Kalmykov, et al., 2019. Ancient human genome-wide data from a 3000-year interval in the Caucasus corresponds with eco-geographic regions. Nature communications 10(1), 590.

Ward, G.K. \& S.R. Wilson, 1978. Procedures for comparing and combining radiocarbon age determinations: a critique. Archaeometry 20(1), 19-31.

Wickham, H., 2016. ggplot2: Elegant Graphics for Data Analysis. New York (NY): Springer.

Willis, C., P. Marshall, J. McKinley, et al., 2016. The dead of Stonehenge. Antiquity 90, 337-56.

\section{Author biographies}

Thomas Booth is a Senior Research Scientist at the Francis Crick Institute. He is interested in the genetic history of prehistoric Britain, as well as bone diagenesis. He has been involved in published archaeogenetic studies of Mesolithic, Neolithic and Bronze Age Britain. 
Joanna Brück is Professor of Archaeology at University College Dublin. She is interested in the treatment of the human body and concepts of self, particularly in Bronze Age Britain and Ireland. One of her forthcoming publications critiques associations of genetic relatedness with kinship in prehistoric societies in Europe.

Selina Brace is a Researcher at the Natural History Museum. She is interested in the study of ancient or degraded DNA in museum specimens to understand evolu- tionary relationships and population histories of organisms. Selina is the lead author on archaeogenetic studies of human populations in Mesolithic, Neolithic and Bronze Age Britain.

Ian Barnes is a Research Leader at the Natural History Museum. He is interested in the analysis of ancient biomolecules, particularly DNA, to understand how organisms adapt and react to changes in their environment. He has directed archaeogenetic publications on the population history of Mesolithic, Neolithic and Bronze Age Britain. 